\title{
APLIKASI METODE PENCUCIAN TERHADAP PENURUNAN JUMLAH BAKTERI PATOGEN PADA SAYURAN SEGAR SELADA (Lactuca sativa L): SYSTEMATIC REVIEW
}

\author{
Ni Putu Wiastari, I Nengah Sujaya* \\ Program Studi Sarjana Kesehatan Masyarakat, Fakultas Kedokteran, Universitas Udayana
}

\begin{abstract}
ABSTRAK
Selada merupakan sayuran segar yang kerap dikonsumsi mentah. Banyaknya kasus keracunan akibat konsumsi selada, karena memiliki risiko tinggi untuk terkontaminasi bakteri patogen, perlu penanganan yang baik sebelum dikonsumsi. Tujuan penelitian ini untuk mengetahui metode pencucian terhadap penurunan bakteri patogen pada selada selama satu dekade terakhir. Systematic Review digunakan dalam penelitian ini. Pencarian literature pada Google Scholar, PubMed, dan ScienceDirect. Kata kunci yang dimasukkan ke database yaitu "Pencucian Selada" dan "Penurunan Bakteri Patogen". Didapatkan 20 artikel yang sesuai dengan kriteria inklusi dan telah dilakukan penilaian kualitas artikel. Berdasarkan 20 artikel, metode pencucian selada diterapkan selama satu dekade terakhir yaitu air mengalir, air oksidasi elektrolisis, air ozon, electrolyzed acidic water, klorin, natrium hipoklorit, persulfat, asam asetat, PAA, cuka, SCFA, belimbing wuluh (Averrhoa bilimbi L), serta sabun pencuci sayuran. Hampir semua metode pencucian mampu mengurangi bakteri patogen pada selada. Namun, penurunan tidak signifikan saat dicuci dengan air mengalir. Hasil review menunjukkan kombinasi klorin dan asam sebagai larutan pencuci merupakan metode yang paling efektif, penurunannya mencapai $5 \mathrm{Log}$ CFU/g atau lebih dari 80\% E.coli O157:H7 pada selada. Berdasarkan hasil review, direkomendasikan kombinasi asam asetat dan jus lemon sebagai larutan pencuci skala rumah tangga, sedangkan penggunaan kombinasi klorin dan asam direkomendasikan untuk skala industri.
\end{abstract}

Kata Kunci: metode pencucian, penurunan bakteri patogen, selada, systematic review

\begin{abstract}
Lettuce is a fresh vegetable that is often consumed raw. Many food posioning has been reported due to lettuce consumption, lettuce has high risk on pathogenic bacterial contamination, therefore it requires proper handling before it is consumed. The purpose this study is review washing methods for decreasing pathogenic bacteria in lettuce over the past decade. Systematic review was used in this study. Literature search on Google Scholar, PubMed, and ScienceDirect with the keyword "Lettuce Washing" and "Decreasing Pathogenic Bacteria". Twenty articles are found that meet as well as article quality. The methods of washing lettuce applied over the past decade that were running water, electrolyzed oxidizing water, ozone water, elektrolyzed acidic water, chlorine, sodium hypochlorite, persulphate, acetic acid, vinegar, short chain fatty acid, peracetic, starfruit (Averrhoa bilimbi $\mathrm{L}$ ), and vegetable washing detergen. All washing methods were able to reduce pathogenic bacteria in lettuce. However, insignificant reduction was found in running water. The study found that combination of chlorine and acid as a washing solution was the most effective method, reduced $5 \mathrm{Log} C F U / g$ or more than $80 \%$ of $E$. coli O157:H7 in lettuce. Based on this study, combination of acetic acid and lemon is recomended for washing method in household scale, while combination of chlorine and acid is recommended in industrial scale.
\end{abstract}

Keywords: washing method, decreasing pathogenic bacteria, lettuce, systematic review

\section{PENDAHULUAN}

Sayuran merupakan salah satu makanan yang sangat penting dikonsumsi untuk mencapai kesehatan yang optimal. Selama beberapa tahun terakhir terjadi peningkatan konsumsi per kapita dari sayuran segar di kalangan masyarakat baik di Indonesia dan negara-negara di dunia salah satunya Amerika (Fishburn \& Frank, 2012). Pada saat ini konsumen tertarik pada produk yang segar, natural, dan diproses secara minimal untuk menjaga kesehatan mereka (Nielsen, 2015).Di negara-negara seperti Eropa dan Amerika sayuran segar kerap dikonsumsi dalam bentuk salad, di indonesia sayuran segar kerap dikonsumsi dalam bentuk salad dan lalapan. Selada merupakan salah satu sayuran segar yang umumnya dikonsumsi dalam keadaan mentah atau tanpa 
pengolahan, selada merupakan komponen utama penyusun salad dan lalapan. Selada dikategorikan sebagai bahan pangan yang beresiko tinggi karena proses pengolahannya yang minim (Hannan, et al., 2014).

Hal utama yang menjadi permasalahan dalam sayuran segar adalah keamanan mikrobiologi (Pardede, 2009). Kontaminasi bakteri patogen pada sayuran segar sering terjadi. Bakteri patogen dianggap sebagai agen yang paling sering menyebabkan foodborne disease seperti Salmonella spp., Shigella spp., Escherichia coli O157:H7, Campylobacter spp., Yersinia spp., Stapyhlococcus aureus dan Listeria spp. (Cetinkaya et al., 2008; WHO, 2008). Bakteri patogen yang biasanya mengontaminasi sayuran segar adalah Salmonella spp. dan E.coli (Banach et al., 2017).

Dengan adanya cemaran atau kontaminasi bakteri patogen pada sayuran segar, sehingga banyak menimbulkan kasus keracunan. Sayuran hijau menjadi pangan tertinggi kasus keracunan makanan dibandingkan jenis pangan lainnya (Herman et al. 2015; Hussain \& Gooneratne, 2017). Risiko tertinggi terjadi ketika sayuran segar tidak dicuci, baik di tingkat petani atau konsumen (Hussain \& Gooneratne, 2017). Beberapa kasus keracunan sayuran segar pada tahun 2018 di Amerika Serikat mewabah karena terdapat E.coli pada selada dilaporkan menyerang 98 orang di 22 wilayah Amerika Serikat. Di Indonesia, sebuah penelitian menunjukkan bahwa kasus keracunan sayuran akibat kontaminasi bakteri meningkat dari tahun ke tahun (Winarti \&Miskiyah, 2010).
Meningkatnya pola konsumsi sayuran yang diolah minimal, dengan begitu penanganan sayuran segar sebelum dikonsumsi menjadi sangat penting. Pencucian yang dilakukan kebanyakan masyarakat indonesia adalah mencuci sayuran segar hanya dengan air mengalir (Zakki, 2015) atau tidak sama sekali mencuci sayuran sebelum dikonsumsi. Berdasarkan penelitian sebelumnya, pencucian dengan air mengalir belum mampu secara signifikan mengurangi cemaran mikroba pada sayuran segar.

Berdasarkan latar belakang yang telah dipaparkan, meningkatnya pola konsumsi sayuran segar yang diolah minimal, meningkatkan risiko keracunan akibat cemaran bakteri patogen, sehingga sangat perlu penanganan sayuran segar sebelum dikonsumsi. Masyarakat dan industri perlu mengetahui metode pencucian untuk pengurangan bakteri patogen pada selada sehingga dapat menurunkan risiko kasus keracunan akibat cemaran bakteri patogen pada selada.

Dengan begitu peneliti bermaksud untuk mengkaji lebih lanjut permasalahan tersebut melalui ulasan sistematik (Systematic review). Nantinya didapatkan metode pencucian yang dapat membantu meningkatkan mutu dan keamanan sayuran segar khususnya selada baik ditingkat rumah tangga atau industri. Tujuan dari Systematic Review ini adalah untuk mengetahui metode pencucian terhadap penurunan jumlah bakteri patogen pada sayuran segar selada berdasarkan hasil penelitian yang telah dilakukan selama satu dekade terakhir. 


\section{METODE PENELITIAN}

Systematic Literature Review (ulasan sistematik) merupakan metode yang digunakan dalam penulisan ini. Dalam penelitian ini peneliti mengkaji permasalahan melalui jurnal-jurnal penelitian baik nasional dan internasional ataupun grey literature. Peneliti melakukan pencarian data melalui portal-portal yang dapat diakses seperti Google Scholar, ScienceDirect dan PubMed. Pencarian data artikel menggunakan kata kunci, kata kunci bahasa Indonesia : "pencucian selada dan penurunan bakteri patogen". Kata kunci bahasa Inggris "Lettuce Washing and Microbial Reduction. Selanjutnya dilakukan tahapan screening yang bertujuan untuk memilih masalah penelitian yang sesuai dengan topik yang diteliti. Penelitian ini discreening berdasarkan pada kriteria sebagai berikut.

Artikel diterbitkan dalam rentang waktu 10 tahun (2010-2020), tipe artikel : research articles, judul berkaitan dengan metode pencucian pada selada untuk pengurangan bakteri patogen, dan artikel yang dapat diakses secara penuh

Adapun kriteria inklusi dan eksklusi yang ditetapkan untuk uji kelayakan artikel sebagai berikut:

Kriteria inklusi

1. Artikel penelitian memiliki desain penelitian eksperimental

2. Studi dalam artikel penelitian membahas metode-metode pencucian pada selada

3. Studi dalam artikel penelitian membahas pengurangan bakteri patogen pada selada dalam bentuk penurunan (log) setelah dilakukan pencucian.

4. Studi dalam artikel penelitian membahas bakteri patogen yang meliputi bakteri aerob mesofilik, Escherichia coli O157: H7, Salmonella, Listeria monocytogenes dan bakteri patogen lainnya

\section{Kriteria Eksklusi}

1. Artikel penelitian memiliki tipe artikel literature review bukan penelitian dengan desain eksperimental

2. Artikel tidak membahas metode pencucian

3. Perlakuan bukan pencucian pada sayuran segar selada.

4. Tidak membahas pengurangan bakteri patogen.

Penilaian Kualitas artikel dilakukan pada artikel yang telah memenuhi kriteria inklusi. Penilaian kualitas artikel menggunakan Tools JBI (The Joanna Briggs Institute) Critical Appraisal Checklist for a Experimental Studies (The Joanna Briggs Institute. 2017), terdapat 9 kriteria yang harus dipenuhi untuk mendapat kualitas artikel yang baik. Kualitas artikel tinggi memenuhi 7-9 poin, kualitas artikel menengah 4-6 poin, kualitas artikel rendah 1-3 poin. Penilaian kualitas artikel juga memperhatikan JIF (Journal Impact Factor), semakin tinggi nilai JIF semakin berkualitas jurnal tersebut.

Selanjutnya dilakukan ekstraksi data, data yang diekstraksi pada setiap studi yang inklusi meliputi penulis, tahun terbit jurnal, judul penelitian, nama jurnal, metode penelitian, kelompok perlakuan, bakteri yang diteliti, hasil penelitian dan 
referensi. Setelah itu sintesis data dilakukan secara kualitatif dengan metode narasi dengan menganalisis isi literatur. 
HASIL

Berdasarkan hasil penelusuran artikel dengan kata kunci pada 3 database yaitu Google Scholar, ScienceDirect, dan PubMed didapatkan 1300 artikel yang telah dilakukan duplicates removal. Selanjutnya dilakukan screening pada artikel, sebanyak 455 artikel yang didapat setelah melalui tahapan screening artikel. Selanjutnya 262 artikel yang telah lolos tahap screening artikel dan dapat diakses full text. Sebanyak 242 dari 262 dieksklusi karena tidak sesuai dengan kriteria inklusi. Hasil akhir artikel yang sesuai dengan kriteria inklusi dan yang akan dilakukan sintesis hasil sebanyak 20 artikel. Artikel yang telah sesuai dengan kriteria inklusi dilakukan penilaian kualitas artikel menggunakan Tools JBI Critical Appraisal Checklist for a Experimental Studies serta memperhatikan JIF (Journal Impact Factor). Hasil dari penilaian kualitas artikel dikategorikan sebagai berikut 13 artikel sangat baik (tinggi), 7 artikel baik (menengah). Sebanyak 14 artikel dari jurnal yang memiliki nilai JIF yang lebih dari 1 sedangkan 6 artikel dari jurnal memiliki nilai JIF kurang dari 1.

Selanjutnya 20 artikel dilakukan ekstraksi data untuk mengelompokan datadata penting pada artikel. Adapun hasil ekstraksi data dapat dilihat pada Tabel 1. hasil ekstraksi data sesuai kriteria inklusi

\section{DISKUSI}

\section{Metode Pencucian Selada dan Efektivitasnya}

Berdasarkan hasil systematic review didapatkan 20 artikel yang telah memenuhi kriteria inklusi mengenai metode pencucian pada selada sebagai upaya pengurangan bakteri patogen. Adapun metode pencucian yang diperoleh serta efektivitasnya berdasarkan artikel yang didapat adalah sebagai berikut

\section{Metode Pencucian dengan Air}

Penggunaan air yang diteliti yaitu air mengalir, air oksidasi elektrolisis, air ozon, dan Electrolyzed acidic water (EAW) serta teknik blansir. Penggunaan air mengalir secara intensif diteliti dalam satu dekade terakhir oleh (Beatriz et al., 2012), (Fishburn \& Frank, 2012), (Davidson \& Ryser, 2013), (Ramos, et al., 2014), (Petri, et al, 2015) dan 5 peneliti lainnya. Penggunaan air mengalir menghasilkan penurunan tertinggi pada E.coli yaitu penurunan 1,69 log CFU/g, penggunaan air mengalir paling lemah efektivitasnya dibanding metode lain yang didapat.

Metode lainnya yaitu air oksdasi elektrolisis dalam satu dekade terakhir diteliti oleh (Fishbun \& Frank., 2012) dan (Qi \& Yen, 2019). Penurunan yang cukup signifikan pada ketiga bakteri patogen yaitu E. coli 0157:H7, Salmonella, dan L.monocytogenes yaitu sekitar 2,8-3,8 log CFU/g. Rendahnya $\mathrm{pH}$ air EO dalam kombinasi dengan ORP tinggi dan klorin bebas, efektif dalam menonaktifkan berbagai mikroorganisme termasuk bakteri gram negatif dan gram positif.

Penggunaan Ozon sebagai larutan pencuci juga diteliti selama satu dekade terakhir oleh (Yasuhiro, et al.,2011) dan (Fishbun \& Frank., 2012). Penggunaan ozon sebagai larutan pencuci memiliki efektivitas yang hampir sama dengan air mengalir yaitu penurunan sekitar 1,5-1,8 
$\log$ CFU/g. Air ozon mampu menonaktifkan spectrum yang luas dari mikroorganisme, termasuk bakteri gram negatif serta merupakan antimikroba yang kuat.

Penggunaan Electrolyzed acidic water sebagai larutan pencuci dalam satu dekade diteliti oleh (Pratama, 2018) didapatkan hasil menyebabkan penurunan sekitar lebih 1 log CFU/g. Electrolyzed water memiliki kemampuan oksidasi-reduksi yang tinggi yang dapat menembus dinding sel mikroorganisme atau memiliki sifat menginaktifkan pertumbuhan mikroorganisme.

Teknik blansir juga diteliti dalam satu dekade terakhir oleh (Metisya,2016). Penggunaan teknik blansir untuk pencucian selada pada suhu $60^{\circ} \mathrm{C}$ selama 5 menit mengakibatkan penurunan bakteri patogen berkisar 2,6 Log CFU/g. Pemanasan pada suhu $60^{\circ} \mathrm{C}$ pada selada sebelum dikonsumsi dapat menetralisir atau membunuh bakteri patogen. Metode ini memiliki potensi dapat menjadi metode pencucian yang efektif terhadap penurunan bakteri patogen, namun artikel yang membahas metode ini hanya satu artikel sehingga tidak ada perbandingan efektivitasnya dan perlu pengkajian lebih mengenai metode pencucian dengan teknik blansir.

\section{Metode Pencucian dengan Sanitizer Kimia}

Berdasarkan hasil review artikel selama satu dekade terakhir, selain penggunaan air penggunaan sanitizer kimia juga secara intensif diteliti. Pencucian dengan sanitizer kimia meliputi klorin, kombinasi klorin dan asam, serta persulfat diaktivasi.

Penggunaan klorin sebagai larutan pencuci selada telah intensif diteliti dalam satu dekade oleh (Keskinen \& Annous, 2011), (Davidson \& Ryser, 2013), (Bencardino, et al.,2018), (Sharma \& Chauhan, 2019), (Fishbun \& Frank., 2012, (Qi \& Yen, 2019) dan (Lippman, et al.,2020). Penurunan yang paling efekif yaitu pada $E$. coli 0157:H7 mengalami penurunan hingga 3,79 Log CFU/g. Klorin mampu menyebabkan reaksi mematikan pada membran sel dan mempengaruhi DNA. Penggunaan klorin 100-200 ppm mampu mengurangi cemaran bakteri patogen. Kelemahan dari penggunaan klorin adalah bersifat karsinogenik, dan berpotensi toksisitas sehingga tidak disarankan digunakan dalam skala rumah tangga.

Penggunaan kombinasi klorin dan asam, metode ini merupakan metode pencucian yang menyebabkan penurunan tertinggi diantara metode lainnya yang didapat. Menurut Davidson \& Ryser (2013), penambahan klorin dengan asam mengakibatkan penurunan 5,47 Log CFU/g. Efektivitas klorin sebagai sanitizer dipengaruhi oleh konsentrasi, suhu dan $\mathrm{pH}, \mathrm{pH}$ dibawah 4, klorin akan terdisosiasi membentuk asam hipoklorit. Asam hipoklorit merupakan suatu senyawa yang berperan paling efektif terhadap daya bunuh mikroba patogen, Peningkatan asam hipoklorit berpengaruh posistif terhadap inaktivasi total mikroba.

Bahan kimia lainnya adalah persulfat yang diteliti oleh (Qi \& Yen, 2019). Pengurangan E. coli O157: H7 dan L. monocytogenes yang menghasilkan 
penurunan hingga 3,5 log CFU/g dalam 5 menit setelah pencucian dengan persulfat. Kelebihan penggunaan persulfat adalah mencegah kontaminasi silang dan tidak mengubah warna kualitas selada. Sehingga persulfat teraktivasi dapat menjadi pembersih alternatif untuk dekontaminasi produk segar.

\section{Metode Pencucian dengan Asam}

Penggunaan asam juga sebagian besar digunakan dalam artikel penelitian selama satu dekade terakhir. Penggunaan asam yang didapatkan meliputi formulasi asam lemak rantai pendek (SCFA), asam asetat, kombinasi asam asetat dan jus lemon, cuka, PAA (asam perasetat) dan belimbing wuluh (Averrhoa bilimbi L).

Penggunaan SCFA (asam lemak rantai pendek) sebagai larutan pencuci diteliti oleh (Keskinen \& Annous, 2011). Formulasi SCFA yang tersusun atas asam kaprilat, surfaktan dan asam laktat mengakibatkan penurunan E.coli lebih dari $5 \log$ CFU/g. Penambahan surfaktan dalam formulasi ini dapat menjadi "agen aktif permukaan" larutan pencuci dapat mengurangi tegangan permukaan larutan sanitasi dan dengan demikian meningkatkan kontak antara sel-sel bakteri dan pembersih yang dapat menghasilkan peningkatan inaktivasi bakteri. $\mathrm{pH}$ rendah (asam) dapat membantu dalam memberikan keefektifan terhadap penurunan bakteri patogen.

Metode asam lainnya yaitu asam asetat diteliti oleh (Nastou et al., 2012), metode ini mengakibatkan pengurangan tertinggi pada Listeria yaitu 2,6 log CFU/g. Kombinasi antara asam asetat dan jus lemon sebagai larutan pencuci juga diteliti, larutan pencuci ini mampu secara signifikan mengurangi salmonella pada selada sebanyak 3,3 log CFU/g. Penggunaan cuka juga diteliti sebagai larutan pencuci selama satu dekade terakhir oleh (Faozia \& Ibrahim, 2017) dan (Ramos et al., 2014). Hasil yang didapat penggunaan cuka yang mengakibatkan penurunan tertinggi yaitu pada cuka balsamic yaitu 2,15 log CFU/g. Cuka dapat menjadi pembersih mikroba yang alami, keasaman yang tinggi pada cuka dapat membunuh bakteri. Adapun kelebihan penggunaan cuka yaitu tidak ada beban organik yang ditimbulkan.

Asam asetat sebagai larutan pencuci dapat menghambat mikroba patogen. Asam asetat dapat merusak fungsi membran dengan mendenaturasi enzim dan mengubah sifat permeabel membran sehingga menjadi tidak stabil. Kombinasi antara asam asetat dan jus lemon dapat menyebabkan penurunan lebih tinggi. Jus lemon mengandung asam sitrat dapat mengganggu $\mathrm{pH}$ optimum dari bakteri dan kandungan flavonoid dapat menembus dinding sel dan membuat permeabilitas sel turun sehingga menyebabkan bakteri lisis.

Penggunaan asam lainnya yaitu PAA (asam perasetat), metode pencucian ini telah intensif diteliti dalam satu dekade terakhir oleh (Petri, et al, 2015), (Qi \& Yen, 2019), (Lippman, et al.,2020), dan (Banach, et al., 2020). PAA ini sebagai larutan pencuci adalah mengalami penurunan tertinggi pada bakteri E. coli 0157:H7 yaitu 5 Log CFU/g. PAA merupakan desinfektan dengan range yang cukup lebar karena memiliki penghambatan terhadap bakteri gram positif dan bakteri gram negatif 
serta yeast dan aktif terhadap spora dan virus pada suhu ruang. Bahan ini mematikan mikroba dengan merusak fungsi protein hingga DNA. Kelebihan dari penggunaan metode ini adalah tidak terpengaruh oleh keberadaan material / zat organik serta tidak membentuk hasil samping reaksi.

Penggunaan asam alami juga diteliti dalam artikel selama satu dekade terakhir sebagai larutan pencuci selada. Menurut Devika,(2019) konsentrasi $25 \%$ selama 5 menit dilakukan pencucian menyebabkan penurunan tertinggi yaitu sekitar 4 log $\mathrm{CFU} / \mathrm{g}$. Belimbing wuluh (Averrhoa bilimbi $L$ ) memiliki komposisi asam organik yang terdiri dari asam asetat,asam sitrat dan asam format dapat menghambat mikroba. Buah belimbing wuluh juga mengandung senyawa flavonoid dan safonin yang menghambat dan mematikan bakteri patogen dan penurun tegangan permukaan yang kuat. Belimbing wuluh memiliki potensi menjadi alternatif yang baik bagi metode pencucian di tingkat rumah tangga karena selain mudah didapatkan, relatif murah, dan tidak menimbulkan efek samping yang membahayakan.

\section{Metode Pencucian dengan Sabun Pencuci} Sayuran

Sabun pencuci sayuran telah intensif diteliti dalam satu dekade terakhir oleh (Siahaan, 2010), (Fishburn \& Frank, 2012), dan (Sharma \& Chauhan, 2019). Secara keseluruhan berdasarkan hasil penelitian yang diujikan pada 3 bakteri patogen yaitu E.coli, Salmonella dan Listeria tidak ada perbedaan yang signifikan terkait efektivitasnya yaitu penurunan yang berkisar 0,5 -0,9 CFU/g. Penggunaan sabun pencuci sayuran bekerja tidak efektif pada struktur sayuran yang memiliki permukaan yang kompleks tetapi dapat mengemulsi lapisan resin dan membantu mengurangi tegangan permukaan.

\section{Metode Pencucian Selada dalam Skala Rumah Tangga dan Industri Pangan}

Adapun metode-metode yang dapat menjadi alternatif dalam pencucian sayuran selada dalam pengurangan bakteri patogen di tingkat rumah tangga berdasarkan hasil review dengan mempertimbangkan aspek mudah didapatkan, relatif murah, dan efektivitasnya dalam pengurangan bakteri patogen adalah penggunaan air dengan teknik blansir, penggunaan bahan-bahan rumah tangga juga dapat digunakan sebagai larutan pencuci yang memiliki efektivitas dalam pengurangan bakteri patogen seperti kombinasi asam asetat dan jus lemon, serta belimbing wuluh (Averrhoa bilimbi $L$ ) yang merupakan bahan alami dan tidak menimbulkan efek samping. Diantara pilihan metode alternatif yang cocok diterapkan dalam skala rumah tangga, metode pencucian dengan kombinasi asam asetat dan jus lemon yang paling efektif dan direkomendasikan untuk skala rumah tangga.

Metode pencucian yang efektif perlu digunakan dalam skala industri pangan, alternatif metode pencucian yang cocok digunakan dalam skala industri mempertimbangan aspek biaya, waktu, aplikatif dan efektivitasnya dalam pengurangan bakteri patogen adalah kombinasi klorin dan asam, klorin sendiri merupakan sanitizer bahan pangan yang secara luas digunakan dalam skala 
industri, penambahan asam pada klorin akan mengakibatkan efektivitas yang maksimal dalam pengurangan bakteri patogen, waktu pencucian yang dibutuhkan juga tidak terlalu lama. Penggunaan asam lemak rantai pendek juga dapat diterapkan dalam skala industri yaitu formulasi SCFA yang tersusun dari asam kaprilat,surfaktan dan asam laktat memberikan penurunan yang signifikan pada bakteri patogen. Penggunaan PAA (asam perasetat) sebagai larutan pencuci dalam waktu singkat dapat menonaktifkan bakteri patogen pada selada dan setelah pencucian menghasilkan COD yang stabil sehingga limbahnya tidak mencemari. Diantara pilihan metode alternatif yang cocok diterapkan dalam skala industri, metode pencucian dengan kombinasi klorin dan asam yang paling efektif dan direkomendasikan untuk skala industri.

\section{SIMPULAN}

Berdasarkan hasil review pada 20 artikel yang memenuhi kriteria inklusi mengenai metode-metode pencucian terhadap penurunan jumlah bakteri patogen pada sayuran segar selada. Secara keseluruhan setelah dilakukan pencucian pada selada dengan berbagai metode yang digunakan, hampir semua metode mengakibatkan penurunan jumlah bakteri patogen. Penggunaan air mengalir dan sabun pencuci sayuran memiliki efektivitas yang tidak signifikan dalam pengurangan bakteri patogen, sedangkan penggunaan kombinasi klorin dan asam sebagai larutan pencuci menjadi metode yang paling efektif dalam pengurangan bakteri patogen berdasarkan artikel yang telah direview yaitu pengurangan $5 \log \mathrm{CFU} / \mathrm{g}$ atau lebih dari 80\% E.coli O157:H7 pada selada.

Berdasarkan metode pencucian yang didapat, beberapa metode pencucian pada selada yang efektif digunakan baik dalam skala industri atau rumah tangga dengan mempertimbangkan aspek mudah didapatkan, mudah diaplikasikan, relatif murah, efisesnsi waktu, aman, serta efektivitasnya tehadap penurunan bakteri patogen. Adapun metode pencucian pada selada yang paling efektif dan direkomendasikan sebagai metode pencucian skala rumah tangga adalah kombinasi asam asetat dan jus lemon, sedangkan metode yang paling efektif dan direkomendasikan sebagai metode pencucian dalam skala industri adalah kombinasi klorin dan asam.

\section{SARAN}

Bagi masyarakat dan industri pangan diharapkan memperhatikan penanganan bahan pangan khususnya sayuran selada yang diolah minimal atau akan dikonsumsi mentah, pembersihan atau pencucian selada sebelum dikonsumsi perlu dilakukan dengan metode pencucian yang tepat sebagai upaya pengurangan bakteri patogen pada selada.

Penggunaan metode pencucian yang tepat dan efektif dapat maksimal dalam pengurangan bakteri patogen. Penggunaan air mengalir saja terbukti belum efektif dalam pengurangan bakteri patogen pada selada. Metode pencucian sayuran selada dengan kombinasi asam dan jus lemon direkomendasikan digunakan dalam skala rumah tangga, sedangkan penggunaan 
kombinasi klorin dan asam direkomendasikan untuk skala industri.

Bagi peneliti selanjutnya Perlu dilakukan penelitian sejenis mengenai metode pencucian pada sayuran segar lainnya yang kerap diolah minimal atau dikonsumsi mentah terhadap pengurangan bakteri patogen guna meningkatkan keamanan sayuran segar dan perlu penelitian systematic review selanjutnya dengan menggunakan analisis secara kuantitatif yaitu meta analisis

\section{UCAPAN TERIMAKASIH}

Ucapan terimakasih disampaikan kepada Ibu Dr. Ni Ketut Sutiari, S.KM.,M.Si, ibu Made Ayu Hitapretiwi Suryadhi, S.Si.MHSc.PH.D, serta ibu Dr. Ir. Komang Ayu Nocianitri, M.Agr.Sc selaku penguji yang telah memberikan masukan yang kritis pada substansi artikel ini.

\section{DAFTAR PUSTAKA}

Banach, J. L, H. van Bokhorst-van de Veen, L.S. van Overbeekc, P.S. van der Zouwen, M.H. Zwieteringd, H.J. van der Fels-Kler .(2020) .Effectiveness of A Peracetic Acid Solution on Escherichia coli Reduction during Fresh-Cut Lettuce Processing at The Laboratory and Industrial Scales. International Journal of Food Microbiology, 321: 108537. Doi: 10.1016/j.ijfoodmicro.2020.108537.

Beatriz, A., R., Eduardo Cesar, T., \& Marisa Itapema, C. (2012).Comparison of Different Washing and Disinfection Protocols Used by Food Services in Southern Brazil for Lettuce (Lactuca sativa). Food and Nutrition Sciences,
3:28-33. Doi: 10.4236/fns.2012.31006.

Bencardino, D., Vitali, L. A. \& Petrelli, D. (2018).Microbiological Evaluation of Ready-To-Eat Iceberg Lettuce during Shelf-Life and Effectiveness of Household Washing Method. Italian Journal of Food Safety, 7: 50-54. Doi: 10.4081/ijfs.2018.6913.

Cetinkaya F, Cibik R, Soyutemiz GE, Ozakin C, Kayali R, Levent B. (2008). Shigella and Salmonella Contamination in Various Foodstuffs in Turkey. Food Control, 19:1059-1063. Doi : 10.1016/j.foodcont.2007.11.004

Davidson, G. R., Buchholz, A. L. and Ryser, E. T. (2013). Efficacy of Commercial Produce Sanitizers against Nontoxigenic Escherichia coli 0157: H7 during Processing of Iceberg Lettuce in A Pilot-Scale Leafy Green Processing Line. Journal of Food Protection, 76(11):1838-1845. Doi: 10.4315/0362-028X.

Devika, Zan Zabila., Elza, Ismail. \& Joko, Susilo.(2019). Pemanfaatan Ekstrak Belimbing Wuluh untuk Pencucian Sayuran dalam Meningkatkan Keamanan Pangan, Ditinjau dari Sifat Fisik dan Daya Terima. [Doctoral Dissertation], Yogyakarta : Poltekkes Kemenkes Yogyakarta.

Faozia, A., \& Ibrahim, A. (2017). Evaluation of Household Sanitizers for Reducing Levels of Salmonella typhimurium on Iceberg Lettuce and Rocket Leaves. Evaluation. International Journal of Sciene and Research Methodology, 5(4):1-12. 
Fishburn, J. D., Tang, Y. \& Frank, J. F. (2012). Efficacy of Various ConsumerFriendly Produce Washing Technologies in Reducing Pathogens on Fresh Produce. Food Protection Trends, 32(8) : 456-466.

Hannan, A., Rehman, R., Saleem, S., Khan, M.U., Qamar, M.U., Azhar, H. (2014). Microbiological analysis of Ready-toeat Salads. International Food Research Journal, 21(5) :1797-1800,

Herman KM, Hall AJ, Gould LH. (2015). Outbreaks Attributed to Fresh Leafy Vegetables. Epidemiology \& Infection, 143(14):3011-3021.Doi: $10.1017 / S 0950268815000047$.

Hussain MA, Gooneratne R. (2017). Understanding The Fresh Produce Safety Challenges.Foods Journal, 6(23): 1-2.Doi: 10.3390/foods6030023.

Inatsu, Y., Kitagawa, T., Nakamura, N., Kawasaki, S., Nei, D., Bari, M. L., \& Kawamoto, S. (2011) .Effectiveness of Stable Ozone Microbubble Water on Reducing Bacteria on the Surface of Selected Leafy Vegetables. Food Science and Technology Research, 17(6) : 479-485. Doi : 10.3136/fstr.17.479

Keskinen, L. A. \& Annous, B. A. (2011). Efficacy of Adding Detergents to Sanitizer Solutions for Inactivation of Escherichia Coli O157 : H7 on Romaine Lettuce. International Journal of Food Microbiology, 147(3): 157-161. Doi:10.1016/j.ijfoodmicro.2011.04.002.

Lippman, B.,Yao, S., Huang, R., \& Chen, H. (2020).Evaluation of The Combined Treatment of Ultraviolet Light and Email korespondensi : nsujaya@unud.ac.id
Peracetic Acid as An Alternative to Chlorine Washing for Lettuce Decontamination. International Journal of Food Microbiology, 232:2-9 Doi:10.1016/j.ijfoodmicro.2020.10859.

Metisya, H. (2016).Perbedaan Pencucian Menggunakan Air Mengalir dan Menggunakan Teknik Blansir Terhadap Pertumbuhan Koloni Bakteri Pada Lalapan Selada (Lactuca sativa L.) Di Warung Makan Kelurahan Jati Kota Padang. [Doctoral Dissertation], Padang : Universitas Andalas

Nastou, A., Rhoades, J., Smirniotis, P., Makri, I., Kontominas, M., \& Likotrafiti, E. (2012). Efficacy of Household Washing Treatments for The Control of Listeria Monocytogenes on Salad Vegetables. International Journal of Food Microbiology, 159: 247253.Doi:

10.1016/j.ijfoodmicro.2012.09.003.

Nielsen, A.C.(2015).We Are What We Eat: Healthy Eating Trends Around The World (Global Health and Wellness Report). New York: The Nielsen Company

Nou, X. \& Luo, Y. (2010). Whole-Leaf Wash Improves Chlorine Efficacy for Microbial Reduction and Prevents Pathogen Cross-Contamination during Fresh-Cut Lettuce Processing. Journal of Food Science, 75(5): 283-290. Doi: 10.1111/j.1750-3841.2010.01630.

Pardede, E. (2009). Buah dan Sayur Olahan Secara Minimalis. [Artikel Ilmiah], Medan : Universitas HKBP Nommensen. 
Petri, E., Rodríguez, M. \& García, S. (2015). Evaluation of Combined Disinfection Methods for Reducing Escherichia coli O157: H7 Population on Fresh-Cut Vegetables. International Journal of Environmental Research and Public health, 12(8): 8678-8690.Doi: 10.3390/ijerph120808678.

Pratama, N. (2018). Efektivitas Desinfeksi Beberapa Jenis Larutan Pencuci dan Pengaruhnya Terhadap Mutu Selada (Lactuca sativa L.) Selama Penyimpanan.[Doctoral Dissertation], Semarang : Universitas Katolik Soegijapranata.

Qi, H. \& Hung, Y. (2019) .Effectiveness of Activated Persulfate in Removal of Foodborne Pathogens from Romaine Lettuce.Food Control, 106:106708. Doi: 10.1016/j.foodcont.2019.106708.

Ramos, B., Brandão, T. R., Teixeira, P., \& Silva, C. L. (2014).Balsamic Vinegar From Modena: An Easy And Effective Approach to Reduce Listeria monocytogenes from Lettuce. Food Control, 42:38-42. Doi: 10.1016/j.foodcont.2014.01.029.

Sharma, A. \& Chauhan, K. (2019).Analysis of Antimicrobial Treatment on Green Leafy Salad Vegetables. International Journal of Current Microbiology and Applied Science, (8): 1-13.

Siahaan, R. (2010).Isolasi Salmonella Spp. Pada Sayuran Segar Di Wilayah Bogor dan Evaluasi Pengaruh Perlakuan

Pencucian Dengan Sanitaiser

Komersial.[Skripsi], Bogor :Fakultas

Teknologi Pertanian Institut

Pertanian Bogor.

The Joanna Briggs Institute. (2017).Critical Appraisal Checklist for Experimental Studies. Available : http://joannabriggs.org/research/critic al-appraisal-tools.html

Uhlig, E., Olsson, C., He, J., Stark, T., Sadowska, Z., Molin, G.\& Håkansson, ̊̊. (2017). Effects of Household Washing on Bacterial Load and Removal of Escherichia Coli from Lettuce and "Ready-To-Eat" Salads. Food Science and Nutrition, 5(6): 1215-1220. Doi: 10.1002/fsn3.514.

WHO (World Health Organization). (2008). Microbiological Hazards in Fresh Leafy vegetable and herbs. Available: http://fao.org/jemra/FFV 2007 Final

Winarti, C \& Miskiyah. (2010). Status kontaminan pada sayuran dan Upaya Pengendaliannya di Indonesia. Pengembangan Inovasi Pertanian,(3): 227-237.

Zakki, G. I. (2015).Pengetahuan dan Perilaku Preventif Terhadap Bakteri E.Coli Pada Masyarakat Kecamatan Gondomanan Di Kota Yogyakarta. [Doctoral Dissertation], Semarang: Universitas Negeri Semarang. 


\section{Lampiran}

Tabel 1. Hasil Ekstraksi Data Sesuai Kriteria Inklusi

\begin{tabular}{|c|c|c|c|c|c|c|c|}
\hline $\begin{array}{l}\text { Penulis / } \\
\text { Tahun }\end{array}$ & $\begin{array}{l}\text { Judul } \\
\text { Penelitian }\end{array}$ & $\begin{array}{l}\text { Nama } \\
\text { Jurnal/JIF }\end{array}$ & $\begin{array}{l}\text { Metode } \\
\text { Penelitia }\end{array}$ & Perlakuan & $\begin{array}{l}\text { Bakteri } \\
\text { yang } \\
\text { diteliti } \\
\end{array}$ & Hasil Penelitian & Referensi \\
\hline $\begin{array}{l}\text { Raja Oloan } \\
\text { Ihotma Siahaan } \\
(2010)\end{array}$ & $\begin{array}{l}\text { Isolasi } \\
\text { Salmonella Spp. } \\
\text { Pada Sayuran } \\
\text { Segar Di } \\
\text { Wilayah Bogor } \\
\text { Dan Evaluasi } \\
\text { Pengaruh } \\
\text { Perlakuan } \\
\text { Pencucian } \\
\text { Dengan } \\
\text { Sanitaiser } \\
\text { Komersial }\end{array}$ & $\begin{array}{l}\text { Scientific } \\
\text { Repository } \\
\text { IPB }\end{array}$ & eksperimental & $\begin{array}{l}\text { Pencucian dengan } \\
\text { perendaman dalam air } \\
\text { matang pada suhu ruang } \\
\text { selama } 30 \text { detik dan } \\
\text { dengan perendaman } \\
\text { dalam larutan sanitaiser } \\
\text { komersial pada suhu } \\
\text { ruang selama } 30 \text { detik }\end{array}$ & Salmonella & $\begin{array}{l}\text { Penurunan kandungan } \\
\text { Salmonella spp. pada selada } \\
\text { setelah dicuci dengan air } \\
\text { matang adalah } 0,4 \text { log CFU/g } \\
\text { atau setara dengan } 36 \% \text {, } \\
\text { sedangkan larutan sanitaiser } \\
\text { komersial dapat menurunkan } \\
\text { hingga } 0,9 \text { log CFU/g yang } \\
\text { setara dengan } 81 \% \text {. }\end{array}$ & $\begin{array}{l}\text { Siahaan, R. (2010).Isolasi } \\
\text { Salmonella Spp. Pada Sayuran } \\
\text { Segar Di Wilayah Bogor dan } \\
\text { Evaluasi Pengaruh Perlakuan } \\
\text { Pencucian Dengan Sanitaiser } \\
\text { Komersial.[Skripsi], Bogor } \\
\text { :Fakultas Teknologi Pertanian } \\
\text { Institut Pertanian Bogor. }\end{array}$ \\
\hline $\begin{array}{l}\text { Xiangwu Nou } \\
\text { and Yaguang } \\
\text { Luo } \\
\text { (2010) } \\
\text { Email l }\end{array}$ & $\begin{array}{l}\text { Whole-Leaf Wash } \\
\text { Improves } \\
\text { Chlorine } \\
\text { Efficacy for } \\
\text { Microbial } \\
\text { Reduction and } \\
\text { Prevents } \\
\text { Pathogen Cross- } \\
\text { Contamination } \\
\text { during Fresh-Cut } \\
\text { Lettuce } \\
\text { Processing } \\
\text { orespondersi : nsuja }\end{array}$ & $\begin{array}{l}\text { Journal of } \\
\text { Food Science } \\
\text { JIF: 2,081 } \\
(2018) \\
\end{array}$ & eksperimental & $\begin{array}{l}\text { Dicuci dalam air yang } \\
\text { diklorinasi } 70 \text { ppm } \\
\text { selama } 1 \text { menit dan } 30 \\
\text { detik sebelum dan setelah } \\
\text { pemotongan. Diulang } \\
\text { pencucian sebanyak } 3 \text { kali }\end{array}$ & $\begin{array}{l}\text { E.coli } \\
\text { O157: H7 }\end{array}$ & $\begin{array}{l}\text { Perlakuan pencucian selada } \\
\text { setelah dipotong di air yang } \\
\text { diklorinasi selama } 60 \text { detik } \\
\text { menghasilkan pengurangan } \\
\text { 1,1 log, sedangkan perlakuan } \\
\text { mencuci seluruh daun selada } \\
\text { dalam air yang diklorinasi } \\
\text { selama } 60 \text { detik menghasilkan } \\
\text { pengurangan } 1,9 \text { unit log. }\end{array}$ & $\begin{array}{l}\text { Nou, X. \& Luo, Y. (2010). Whole- } \\
\text { Leaf Wash Improves Chlorine } \\
\text { Efficacy for Microbial Reduction } \\
\text { and Prevents Pathogen Cross- } \\
\text { Contamination during Fresh-Cut } \\
\text { Lettuce Processing. Journal of Food } \\
\text { Science, } 75(5) \text { : 283-290. Doi: } \\
\text { 10.1111/j.1750-3841.2010.01630. }\end{array}$ \\
\hline $\begin{array}{l}\text { Lindsey A. } \\
\text { Keskinen, }\end{array}$ & $\begin{array}{l}\text { Efficacy of adding } \\
\text { detergents to }\end{array}$ & $\begin{array}{l}\text { International } \\
\text { Journal of }\end{array}$ & eksperimental & $\begin{array}{l}\text { Perlakuan pencucian } \\
\text { selada dengan, }\end{array}$ & $\begin{array}{l}\text { E.coli } \\
\text { O157: H7 }\end{array}$ & $\begin{array}{l}\text { Perlakuan pencucian } \\
\text { yang paling efektif adalah }\end{array}$ & $\begin{array}{l}\text { Keskinen, L. A. \& Annous, B. A. } \\
\text { (2011). Efficacy of Adding }\end{array}$ \\
\hline
\end{tabular}




\begin{tabular}{|c|c|c|c|}
\hline $\begin{array}{l}\text { Bassam A. } \\
\text { Annous } \\
(2011)\end{array}$ & $\begin{array}{l}\text { sanitizer } \\
\text { solutions for } \\
\text { inactivation of } \\
\text { Escherichia coli } \\
\text { O157:H7 on } \\
\text { Romaine lettuce }\end{array}$ & $\begin{array}{l}\text { Food } \\
\text { Microbiology } \\
\text { JIF : 4,006 } \\
(2018)\end{array}$ & $\begin{array}{l}\text { 1. formulasi asam lemak } \\
\text { rantai pendek (SCFA), } \\
\text { 2. air denionisasi, } \\
\text { 3. } 100 \text { ppm klor dioksida, } \\
\text { 4. } 100 \text { ppm klorin, } \\
\text { 5. } 200 \text { ppm klorin }\end{array}$ \\
\hline
\end{tabular}

Detergents to Sanitizer Solutions for Inactivation of Escherichia coli O157 : H7 on Romaine Lettuce. International Journal of Food Microbiology, 147(3):

157-

161.Doi:10.1016/j.ijfoodmicro.2011.04 pencucian, untuk perlakuan pencucian lainnya menghasilkan pengurangan populasi E.coli kurang dari 1 $\log \mathrm{CFU} / \mathrm{g}$.

\begin{tabular}{|c|c|c|c|}
\hline $\begin{array}{l}\text { Yasuhiro } \\
\text { Inatsu, et al } \\
(2011)\end{array}$ & $\begin{array}{l}\text { Effectiveness of } \\
\text { Stable Ozone } \\
\text { Microbubble } \\
\text { Water on } \\
\text { Reducing } \\
\text { Bacteria on the } \\
\text { Surface } \\
\text { of Selected Leafy } \\
\text { Vegetables }\end{array}$ & $\begin{array}{l}\text { Food Science eksperimental } \\
\text { and } \\
\text { Technology } \\
\text { Research } \\
\text { JIF : } 0,448 \\
(2018 / 2019)\end{array}$ & $\begin{array}{l}\text { Perlakuan yang } \\
\text { dilakukan adalah } \\
\text { pencucian dengan } \\
\text { 1. Air Suling } \\
\text { 2. Sodium Hipoklorit } \\
\text { 3. Air gelembung mikro } \\
\text { Ozon } \\
\text { 4. Air Ozon } \\
\text { 5. Ozon berbentuk Gas }\end{array}$ \\
\hline
\end{tabular}

$\begin{array}{ll}\text { E. coli } & \text { Mencuci dengan DW, OW dan } \\ \text { O157: H7 } & \text { OMBW mengurangi E. coli } \\ & \text { O157: H7 yang menempel } \\ & \text { pada permukaan sekitar 0,5 } \\ & \text { hingga 1,0 log CFU / g. 0,3 } \\ & \text { hingga 1,0 log CFU / g } \\ & \text { efektivitas bakterisida yang } \\ & \text { lebih tinggi diamati ketika } \\ & \text { larutan NaCLO 100 mg / L. } \\ & \text { digunakan untuk mencuci }\end{array}$
E. coli digunakan untuk mencuci

.002 .

pendek) yang dapat

mengurangi populasi E.coli

O157: H7 sebanyak lebih dari

\begin{tabular}{lll}
\hline Aikaterini & Efficacy of & International eksperimental \\
Nastou, Et al & household & Journal of \\
(2012) & washing & Food \\
& treatments for the & Microbiology \\
& control of Listeria & \\
& monocytogenes & JIF : 4,006 \\
& on salad & $(2018)$ \\
& &
\end{tabular}

Email korespondensi : nsujaya@unud.ac.id

Mencelupkan sayuran ke
dalam larutan asam asetat
( pka 4,75 ) dengan
berbagai konsentrasi dan
waktu pemaparan $0,5 \%$,
$1,0 \%, 1,5 \%$ dan $2,0 \% 5$
hingga 30 menit

hingga 30 menit

$\begin{array}{ll}\text { L. } & \text { Penocytog } \\ \text { enes } & \text { suh } \\ & \text { pen } \\ & \text { Pen } \\ & \text { den } \\ & \text { kor } \\ & \text { tert }\end{array}$

Perendaman dalam air pada suhu $30^{\circ} \mathrm{C}$ menyebabkan penurunan $L$. monocytogenes $0,8 \log \mathrm{CFU} / \mathrm{cm}^{2}$.

Pengurangan yang lebih tinggi dengan meningkatnya

konsentrasi, pengurangan tertinggi yang diamati dengan konsentrasi asam asetat 2,0\% sebanyak 2,6 log CFU/g.
Inatsu, Y., Kitagawa, T., Nakamura, N., Kawasaki, S., Nei, D., Bari, M. L., \& Kawamoto, S. (2011).

Effectiveness of Stable Ozone

Microbubble Water on Reducing Bacteria on the Surface of Selected Leafy Vegetables. Food Science and Technology Research, 17(6) : 479-485. Doi : 10.3136/fstr.17.479

Nastou, A., Rhoades, J., Smirniotis, P., Makri, I., Kontominas, M., \& Likotrafiti, E. (2012). Efficacy of Household Washing Treatments for The Control of Listeria monocytogenes on Salad Vegetables. International Journal of Food Microbiology, 159: 247253.Doi:10.1016/j.ijfoodmicro.2012.09 .003 . 


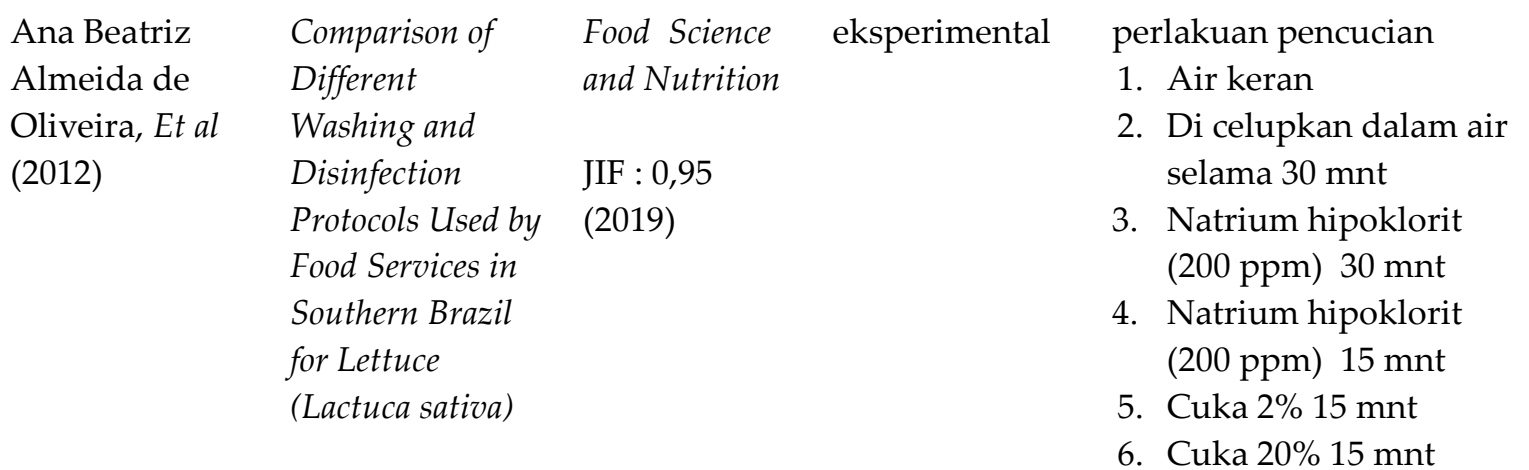

aerob Pengurangan terbesar dalam mesofilik total bakteri aerob mesofilik ditemukan untuk perawatan natrium hipoklorit (200 ppm klorin) selama 30 menit, dengan pengurangan $2,46 \log _{10}$ CFU / g Perlakuan cuka 20\% menyebabkan penurunan lebih baik dari air . pengurangan terkecil mikroorganisme aerob ditemukan dalam perawatan yang hanya menggunakan air

\begin{tabular}{llll}
\hline Jillian D. & Efficacy Of & Journal of & eksperimental \\
Fishburn, & Various & Food & \\
Yanjie Tang & Consumer & Protection \\
dan Joseph F. & Friendly Produce & \\
Frank & Washing & JIF : 1,559 \\
$(2012)$ & Technologies In & $(2018)$ \\
& Reducing & \\
& Pathgogens On & \\
& Fresh Produce &
\end{tabular}

2. sabun pencuci sayuran

komersil,

3.air ozon,

4. air oksidasi elektrolisis,

5. klorin encer.

Air pada penurunan bakteri patogen sekitar $1 \log$ unit.

Pencucian dengan

menggunakan sabun pencuci sayuran komersil kurang efektif terhadap penurunan

E.coli dan L.monocytogenes.

perlakuan pencucian Salmonella Air pada penurunan bakteri

perlakuan pencucian

Salmonella
,E. coli
O157:
H7 dan L.
monocytog
ene
pencucian dengan klorin penurunan Salmonella 2,05 log. Namun klorin ini lebih efektif dalam mengurangi E.coli O157: H7. Metode air oksidasi elektrolisis lebih efektif dari air lebih dari $3 \log$.

\begin{tabular}{|c|c|c|c|c|c|c|}
\hline $\begin{array}{l}\text { Gordon R. } \\
\text { Davidson, } \\
\text { Annemarie L. } \\
\text { Buchholz, And }\end{array}$ & $\begin{array}{l}\text { Efficacy of } \\
\text { Commercial } \\
\text { Produce } \\
\text { Sanitizers against }\end{array}$ & $\begin{array}{l}\text { Journal of } \\
\text { Food } \\
\text { Protection }\end{array}$ & eksperimental & $\begin{array}{l}\text { perlakuan pencucian } \\
\text { 1. air saja } \\
\text { 2. } 50 \text { ppm asam } \\
\text { peroksiasetat }\end{array}$ & $\begin{array}{l}\text { E. coli } \\
\text { 0157:H7 }\end{array}$ & $\begin{array}{l}\text { Penurunan populasi E.coli } \\
\text { secara signifikan pada selada } \\
\text { setelah ditambahan peracid, } \\
\text { dan klorin atau klor dan }\end{array}$ \\
\hline
\end{tabular}

Fishburn, J. D., Tang, Y. \& Frank, J. F. (2012). Efficacy of Various Consumer Friendly Produce Washing

Technologies in Reducing Pathogens on Fresh Produce. Food Protection Trends, 32(8) : 456-466.

Marisa Itapema, C.

(2012).Comparison of Different

Washing and Disinfection Protocols Used by Food Services in Southern Brazil for Lettuce (Lactuca sativa). Food and Nutrition Sciences, 3:28-33. Doi: 10.4236/fns.2012.31006.

\author{
Davidson, G. R., Buchholz, A. L. and \\ Ryser, E. T. (2013).Efficacy of \\ Commercial Produce Sanitizers \\ against Nontoxigenic Escherichia coli
}




\begin{tabular}{|c|c|c|c|}
\hline $\begin{array}{l}\text { Elliot T. Ryser } \\
\text { (2013) }\end{array}$ & $\begin{array}{l}\text { Nontoxigenic } \\
\text { Escherichia coli } \\
\text { 0157:H7 during } \\
\text { Processing of } \\
\text { Iceberg Lettuce } \\
\text { ina Pilot-Scale } \\
\text { Leafy Green }\end{array}$ & $\begin{array}{l}\text { JIF }: 1,559 \\
(2018)\end{array}$ & $\begin{array}{l}\text { 3. } 50 \text { ppm peracid } \\
\text { 4. } 50 \text { Klorin dan klorin } \\
\text { yang diasamkan dengan } \\
\text { asam sitrat }\end{array}$ \\
\hline $\begin{array}{l}\text { B. Ramos, } \\
\text { T.R.S. Brandão, } \\
\text { P. Teixeira, } \\
\text { C.L.M. Silva } \\
\text { (2014) }\end{array}$ & $\begin{array}{l}\text { Balsamic vinegar } \\
\text { from Modena: An } \\
\text { easy and effective } \\
\text { approach to } \\
\text { reduce Listeria } \\
\text { monocytogenes } \\
\text { from lettuce }\end{array}$ & $\begin{array}{l}\text { International eksperimental } \\
\text { Journal of } \\
\text { Food } \\
\text { Microbiology } \\
\text { JIF : } 4,006 \\
(2018)\end{array}$ & $\begin{array}{l}\text { Selada di beri perlakuan } \\
\text { 1. Air saja (kontrol) } \\
\text { 2. Cuka Balsamic } \\
\text { 3. Cuka Anggur putih } \\
\text { 4. Asam Asetat }\end{array}$ \\
\hline
\end{tabular}

ditambah CA yaitu

$(1,4),(3,79),(5,47) \mathrm{CfU} / \mathrm{g}$ setelah pencucian 90s. Perlakuan pencucian dengan berbagai klorin lebih efektif daripada menggunakan air saja.
Pencucian dengan

monocytog menggunakan air biasa hanya enes mampu mengurangi 0,05 log.

L. monocyotogenes. Tetapi penurunan terbesar adalah pengunaan cuka balsamic, Penurunan bakteri pada masing masing perlakuan Cuka balsamic 50\% yaitu (CFU/ml): 2,15, Cuka Putih $50 \%: 1,18$, Asam asetat 50\% : 1,13

\begin{tabular}{lll}
\hline Eva Petri, & $\begin{array}{l}\text { Evaluation of } \\
\text { Combined }\end{array}$ & $\begin{array}{l}\text { International } \\
\text { Journal of }\end{array}$ \\
Rodríguez dan & Disinfection & Environmenta \\
Silvia García & Methods for & l Research and \\
$(2015)$ & Reducing & Public Health \\
& Escherichia coli & JIF : 2,468 \\
& Population on & $(2018)$ \\
& Fresh-Cut & \\
& Vegetables & \\
& & \\
\hline Hasna & Perbedaan & E-Journal \\
Metisya & Pencucian & Universitas \\
(2016) & Menggunakan & Andalas \\
& Email korespondensi : nsujaya@unud.ac.id
\end{tabular}

eksperimental

Setelah diinokulasi selada dilakukan pencucian

dengan perlakuan

1. air biasa dan air yang diklorinasi (kontrol): 65 ppm

2. klor dioksida (clo2) $: 2$ $\mathrm{mg} / \mathrm{L}$

3. Asam peroksiasetat: $100 \mathrm{mg} / \mathrm{L}$

Penelitian ini Perlakuan pencucian dengan menggunakan desain pre and

1. Tanpa perlakuan

E. coli

0157:H7

Hasilnya menunjukkan bahwa Populasi dari E. coli secara signifikan menurun Masing-masing penurunannya $\log$ CFU/g. klorin : 2,49, PAA : 2,21, Klorin dioksida : 1,41, Air : 1,41. Mencuci dengan air ledeng saja tidak bisa mengurangi kontaminasi.
0157 : H7 during Processing of

Iceberg Lettuce in a Pilot-Scale Leafy Green Processing Line. Journal of Food Protection, 76(11):1838-1845. Doi: 10.4315/0362-028X.

\section{Ramos, B., Brandão, T. R., Teixeira,}

P., \& Silva, C. L. (2014).Balsamic

Vinegar From Modena : An Easy and Effective Approach to Reduce Listeria monocytogenes From Lettuce. Food Control, 42:38-42. Doi: 10.1016/j.foodcont.2014.01.029.

Email korespondensi : nsujaya@unud.ac.id 
Air Mengalir

Dan

post

(kontrol)

Menggunakan

Teknik Blansir

Terhadap

Pertumbuhan

Koloni Bakteri

Pada Lalapan

Selada (Lactuca

Sativa L.)

Di Warung

Makan

Kelurahan Jati

Kota Padang

\begin{tabular}{ll}
\hline Elisabeth & Effects of \\
Uhlig, Et al & household \\
(2017) & washing on \\
& bacterial load and \\
& removal of \\
& Escherichia coli \\
& from lettuce and \\
& "ready-to- \\
& eat" \\
& salads
\end{tabular}

\begin{tabular}{lll}
\hline Faozia A. & Evaluation of & International \\
Ibrahim, Radya & Household & Journal of \\
A. Mustafa, & Sanitizers for & Science and \\
Suleiman & Reducing Levels & Research \\
Abusalloum, & of Salmonella & Methodology \\
M.S. Eljadar & typhimurium on \\
(2017) & Iceberg Lettuce & JIF : 4,598 \\
& and Rocket Leaves & $(2018)$ \\
\multicolumn{3}{c}{ Email korespondensi : nsujaya@unud.ac.id }
\end{tabular}

\section{Food Science}

and Nutrition

JIF : 0,95
2. Pencucian dengan air mengalir

3. Pencucian dengan teknik blansir $60^{\circ} \mathrm{C}$ selama 1 menit, 3 menit dan 5 menit selada yang dicuci

menggunakan air mengalir adalah 268,8 cfu/gr, selada yang dicuci menggunakan teknik blansir selama 1 menit, 3 menit, dan 5 menit masingmasing 23,4 CFU/gr, 5,85 $\mathrm{CFU} / \mathrm{gr}$, dan $0 \mathrm{CFU} / \mathrm{gr}$.
Pertumbuhan Koloni Bakteri Pada Lalapan Selada (Lactuca sativa L.) Di Warung Makan Kelurahan Jati Kota Padang. [Doctoral Dissertation], Padang : Universitas Andalas eksperimental

Selada yang tersisa

kemudian dicuci oleh dua prosedur yang berbeda

1. Tidak dicuci

2. Membilas dalam saringan di bawah air mengalir dengan aliran air sebesar $2 \mathrm{~L} /$ menit dan $8 \mathrm{~L} /$ menit

3. perendaman dalam wadah dengan air

eksperimental

Diberi perlakuan pencucian dengan produk rumah tangga

1. Dicelupkan ke air suling 1,5 L selama 30 menit

2. air yang mengandung cuka $1,5 \%$ selama 30
Salmonella Pencucian dengan pada larutan natrium hipoklorit 200 ppm selama 2 menit

\section{Escherichi Tanpa dicuci selada yang}

a coli diinokulasi E.coli memiliki

O157: H7 nilai rata-rata 5,0 log 10 CFU /

g. Setelah pencucian pertama jumlah E.coli menurun 4,2 log $10 \mathrm{CFU} / \mathrm{g}$ dan setelah pencucian ke 5 jumlah E.coli menurun 3,9 log $10 \mathrm{CFU} / \mathrm{g}$.

mengurangi S.typhimurium pada sampel 0,1 log $10 \mathrm{CFU} /$ g. Campuran lemon jus dan cuka (1: 1), populasi awal berkurang hingga 3,3 dan 2,7
Uhlig, E., Olsson, C., He, J., Stark, T. . Sadowska, Z., Molin, G.\&

Håkansson, Å. (2017). Effects of

Household Washing on Bacterial

Load and Removal of Escherichia coli From Lettuce and "Ready-To-Eat" Salads. Food Science and Nutrition, 5(6): 1215-1220. Doi: 10.1002/fsn3.514.

Faozia, A., \& Ibrahim, A. (2017) Evaluation of Household Sanitizers for Reducing Levels of Salmonella typhimurium on Iceberg Lettuce and Rocket Leaves. Evaluation. International Journal of Sciene and Research Methodology, 5(4):1-12. 
menit

3. Larutan Natrium

hipoklorit 200 ppm

4. Campuran jus lemon

dan cuka (asam asetat)

$0,086 \%$ ) $\log 10$ CFU / g setelah 15 dan 30 menit. Menariknya, pada inokulum rendah, semuanya perawatan yang diterapkan (kecuali air suling)

\begin{tabular}{ll}
\hline Daniela & Microbiological \\
Bencardino, & evaluation of \\
Luca Agostino & ready-to-eat \\
Vitali, & iceberg lettuce \\
Dezemona & during shelf-life \\
Petrell & and effectiveness \\
(2018) & of household \\
& washing methods
\end{tabular}

$\begin{aligned} & \text { Italian Journal eksperimental } \\ & \text { of Food Safety }\end{aligned}$
JIF : 0,970
$(2019)$

Perendaman pada
1. air keran $(500 \mathrm{ml})$
2. Air+bikarbonat
3. Air keran + NaCL $(4$
g)
4. Air keran + cuka $(10$
ml)
5. Air keran + klorin $(10$
ml )
waktu (0 detik, 15 menit
dan 30 menit $)$
Escherichi Untuk selada yang dicuci
a coli dengan air menyebabkan
Salmonella reduksi yang lemah pada
spp. dan patogen yaitu $4 \%$ dalam
Listeria waktu 30 menit. Untuk
monocytog pencucian dengan NaCL pada
enes
15 menit dan 30 menit
berkurang $4 \%$ dan sedangkan
pencucian dengan air dan
cuka mengalami penurunan
yang lebih besar yaitu $22 \%$
setelah 30 menit pencucian.
Pencucian air dengan klorin
juga mengalami penurunan
yang signifikan yaitu lebih
dari 70\% selama 30 menit.

\begin{tabular}{|c|c|c|c|c|c|c|}
\hline $\begin{array}{l}\text { Nita Pratama } \\
(2018)\end{array}$ & $\begin{array}{l}\text { Efektivitas } \\
\text { Desinfeksi } \\
\text { Beberapa Jenis } \\
\text { Larutan Pencuci } \\
\text { Dan } \\
\text { Pengaruhnya } \\
\text { Terhadap Mutu } \\
\text { Selada (Lactuca } \\
\text { Sativa L.) }\end{array}$ & $\begin{array}{l}\text { E-Journal } \\
\text { Unika }\end{array}$ & eksperimental & $\begin{array}{l}\text { Empat cairan yang } \\
\text { digunakan yaitu } \\
\text { 1. electrolyzed acidic } \\
\text { water (EAW), } \\
\text { 2. electrolyzed reduced } \\
\text { water (ERW), } \\
\text { 3. } \mathrm{Ca}(\mathrm{ClO}) 2 \text {, } \\
\text { 4. air kran sebagai kontrol }\end{array}$ & $\begin{array}{l}\text { Bakteri } \\
\text { patogen }\end{array}$ & $\begin{array}{l}\text { Pertumbuhan koloni setelah } \\
\text { dicuci dengan larutan pencuci } \\
\text { EAW masih tergolong rendah } \\
\text { dibandingkan dengan larutan } \\
\text { pencuci lainnya. Peningkatan } \\
\text { jumlah koloni tertinggi terjadi } \\
\text { pada hari ke- } 8 \text { dengan } \\
\text { pencucian } \mathrm{Ca}(\mathrm{ClO}) 2 \text { serta hari } \\
\text { ke-10 dengan pencucian ERW }\end{array}$ \\
\hline
\end{tabular}


Selama

Penyimpanan dan kran. EAW memiliki daya

antimikrob yang lebih tinggi,

karena nilai ORP EAW

menjadi lebih tinggi.

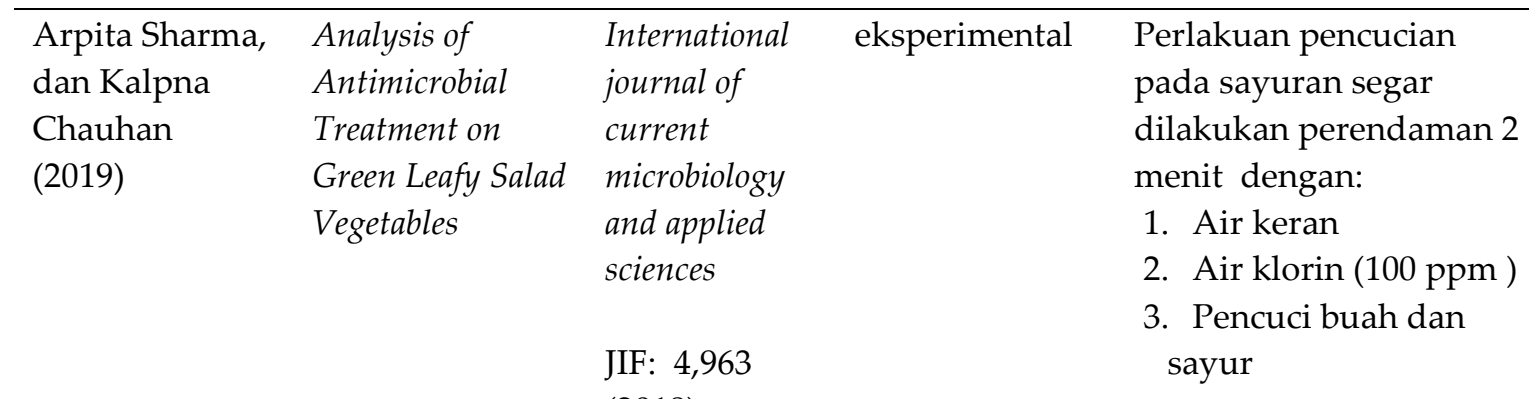

Bakteri
patogen

Hasil penelitian menunjukkan bahwa dalam pengenceran $10^{2}$ $-10^{-6}$ pada kontrol berkisar antara 2,37-2,19 $\log _{10} \mathrm{CFU} / \mathrm{g}$. Pencucian dengan air keran menyebabkan penurunan minimal pada pengenceran $10^{2}$ $-10^{-}{ }^{6}$ berkisar $2,32-2,13 \log 10$ $\mathrm{CFU} / \mathrm{g}$, pencucian dengan klorin penurunannya 1,88-1,79 $\log { }_{10} \mathrm{CFU} / \mathrm{g}$ pencucian dengan pencuci sayur dan buah menyebabkan penurunan 1,61-1,5 log $10 \mathrm{CFU}$ / g dan tidak ada pertumbuhan bakteri dalam air klorin dan pencuci sayur dan buah pada pengenceran $10^{-4}-10^{-6}$.
Sharma, A. \& Chauhan, K.

(2019).Analysis of Antimicrobial

Treatment on Green Leafy Salad

Vegetables. International Journal of Current Microbiology and Applied Science, (8): 1-13.

\begin{tabular}{ll}
\hline Devika, Zan & Pemanfaatan \\
Zabila dan Elz & Ekstrak \\
a, & Belimbing \\
Ismail dan Jok & Wuluh Untuk \\
O, Susilo & Pencucian \\
$(2019)$ & Sayuran Dalam \\
& Meningkatkan \\
& Keamanan
\end{tabular}

Email korespondensi : nsujaya@unud.ac.id

\begin{tabular}{|c|c|c|c|c|}
\hline $\begin{array}{l}\text { Jurnal Induk } \\
\text { Nasional } \\
\text { Kesehatan } \\
\text { Kemenkes RI }\end{array}$ & $\begin{array}{l}\text { eksperimental } \\
\text { semu dengan } \\
\text { rancangan acak } \\
\text { sederhana }\end{array}$ & $\begin{array}{l}\text { Perendaman sayur } \\
\text { lalapan pada ekstrak } \\
\text { belimbing wuluh } 25 \% 5 \\
\text { menit dan } 20 \text { menit }\end{array}$ & $\begin{array}{l}\text { Bakteri } \\
\text { Patogen }\end{array}$ & $\begin{array}{l}\text { Terdapat penurunan angka } \\
\text { kuman setelah dilakukan } \\
\text { perendaman dengan } \\
\text { menggunakan esktrak } \\
\text { belimbing wuluh. Penurunan } \\
\text { angka kuman pada selada } \\
\text { paling tinggi yaitu pada } \\
\text { perendaman dengan }\end{array}$ \\
\hline
\end{tabular}

Devika, Zan Zabila., Elza, Ismail. \& Joko, Susilo.(2019). Pemanfaatan Ekstrak Belimbing Wuluh untuk Pencucian Sayuran dalam Meningkatkan Keamanan Pangan, Ditinjau dari Sifat Fisik dan Daya Terima. [Doctoral dissertation], Yogyakarta : Poltekkes Kemenkes 
Pangan,

Ditinjau Dari

Sifat Fisik Dan

Daya Terima

$\begin{array}{lll}\text { Hang Qi, Yen- } & \begin{array}{l}\text { Effectiveness of } \\ \text { activated }\end{array} & \begin{array}{l}\text { International } \\ \text { Journal of }\end{array} \\ \text { (2019) } & \text { persulfate in } & \text { Food } \\ & \text { removal of } & \text { Microbiology } \\ & \text { foodborne } & \text { JIF : 4,006 } \\ & \text { pathogens } & (2018) \\ & \text { from romaine } & \\ & \text { lettuce } & \end{array}$

eksperimental

Perlakuan yang

dilakukan adalah

pencucian dengan

1. Air pengoksidasi elektrolisa (EO) 100

$\mathrm{mg} / \mathrm{L}$ klor

2. PAA $(78 \mathrm{mg} / \mathrm{L})$

3. Pemutih Encer (100 $\mathrm{mg} / \mathrm{L}$ )

4. Natrium Hidroksida (200 dan $20 \mathrm{mmol} / \mathrm{L}$ )

5. Persulfat diaktivasi basa dan besi 700 dan $70(\mathrm{mmol} / \mathrm{L})$

Semua perlakuan dilakukan selama 5 menit pada suhu $20^{\circ} \mathrm{C}$ dan $4^{\circ} \mathrm{C}$ menggunakan ekstrak

belimbing wuluh selama 5

menit dengan jumlah bakteri

sebanyak $0,675 \times 10^{5} \mathrm{CFU} / \mathrm{g}$.
Yogyakarta

$\begin{array}{ll}\text { Escherichi } & \text { Perlakuan persulfat yang } \\ \text { a coli } & \text { diaktifkan dan EO mencapai } \\ \text { O157: H7 } & \text { pengurangan yang signifikan } \\ \text { dan } & \text { lebih tinggi diatas 3 log CFU/g } \\ \text { Listeria } & \text { pada E.coli dan L. } \\ \text { monocytog } & \text { Monocytogenes dibanding } \\ \text { enes } & \text { dengan perlakuan lainnya. } \\ & \text { PAA dan pemutih } \\ & \text { memperoleh pengurangan } \\ & \text { sekitar 2,9 log CFU/g mereka } \\ & \text { masih lebih efektif dari } \\ & \text { natrium hidroksida (2,5 log } \\ & \text { CFU / g) dan besi sulfat (2.3 } \\ & \text { log CFU /g) }\end{array}$

Qi, H. \& Hung, Y. (2019).

Effectiveness of Activated Persulfate in Removal of Foodborne Pathogens from Romaine Lettuce.Food Control, 106:106708. Doi:

10.1016/j.foodcont.2019.106708.

\begin{tabular}{|c|c|c|}
\hline $\begin{array}{l}\text { Beth Lippman, } \\
\text { Shiyun Yao, } \\
\text { Runze Huang, } \\
\text { Haiqiang Chen } \\
(2020)\end{array}$ & $\begin{array}{l}\text { Evaluation of the } \\
\text { combined } \\
\text { treatment of } \\
\text { ultraviolet light } \\
\text { and peracetic acid } \\
\text { as an alternative } \\
\text { to chlorine } \\
\text { washing for } \\
\text { lettuce } \\
\text { decontamination }\end{array}$ & $\begin{array}{l}\text { International } \\
\text { Journal of } \\
\text { Food } \\
\text { Microbiology } \\
\text { JIF : 4,006 } \\
(2018)\end{array}$ \\
\hline
\end{tabular}

Email korespondensi : nsujaya@unud.ac.id

eksperimental

Perlak

dengan

1) 10 dan 20 ppm klorin bebas,

2) solusi PAA (40 dan 80 ppm),

Salmonella

a

Di antara semua perawatan

tunggal Untuk kelompok

perlakuan 2 menit, sedangkan

80 ppm PAA dan 20 ppm

klorin bebas menghasilkan pengurangan 1,52 dan 1,23 log.

Untuk kelompok perlakuan 5 menit, pengobatan gabungan menghasilkan pengurangan 3,24 log, sedangkan pencucian
Lippman, B.,Yao, S., Huang, R., \&

Chen, H. (2020).Evaluation of The

Combined Treatment of

Ultraviolet Light and Peracetic

Acid as an Alternative to Chlorine Washing For Lettuce

Decontamination. International

Journal of Food Microbiology, 232:2-9 Doi:10.1016/j.ijfoodmicro.2020.1085 
klorin 20 ppm hanya mencapai 9 . pengurangan 1,24 log.

\begin{tabular}{lll}
\hline J.L. Banacha, Et & Effectiveness of a & International \\
al & peracetic acid & Journal of \\
(2020) & solution on & Food \\
& Escherichia coli & Microbiology \\
& reduction during & \\
& fresh-cut lettuce & JIF : 4,006 \\
& processing at the & $(2018)$ \\
& laboratory and & \\
& industrial scales &
\end{tabular}

\section{eksperimen \\ Percobaan di}

skala

laboratorium

dan dievaluasi

di industri

industrial scales laboratorium

menggunakan pencucian

dengan

1. Tidak diberikan PAA

(kontrol)

2. PAA (75 mg/ L)

Dengan jenis air air

minum, air dengan TOC

$500 \mathrm{mg} / \mathrm{l}$ dan air dengan

TOC $750 \mathrm{mg} / \mathrm{l}$
Escherichi Penggunaan PAA tidak

a coli terpengaruh oleh beban

organik di dalam air.Seperti

yang diamati oleh

pengurangan sekitar 5 log dari

E. coli di dalam air.

penggunaan larutan PAA (ca

$75 \mathrm{mg} / \mathrm{L}$ ) adalah Disinfektan air cuci yang efektif dan aman yang berpotensi digunakan pada skala industri
Banach, J. L, H. van Bokhorst-van de Veen, L.S. van Overbeekc, P.S. van der Zouwen, M.H.

Zwieteringd, H.J. van der Fels-Kler .(2020) .Effectiveness of A Peracetic Acid Solution on Escherichia coli

Reduction during Fresh-Cut

Lettuce Processinga at The

Laboratory and Industrial Scales. International Journal of Food Microbiology, 321: 108537. Doi: 10.1016/j.ijfoodmicro.2020.108537. 